\title{
Short- and Long-Term Impacts of Workplace Relocation: A Survey and Experience from the University of Luxembourg Relocation
}

\author{
François Sprumont ${ }^{1}$, Ali Shateri Benam ${ }^{2}$ (D) and Francesco Viti ${ }^{3, *(1)}$ \\ 1 Movesion Luxembourg, Esch-sur-Alzette, L-4362 Luxembourg, Luxembourg; \\ francois.sprumont@movesion.com \\ 2 Department of Engineering, University of Rome, La Sapienza, 00185 Rome, Italy; ali.sh.benam@gmail.com \\ 3 MobiLab Transport Research Group, University of Luxembourg, Esch-sur-Alzette, \\ L-4364 Luxembourg, Luxembourg \\ * Correspondence: francesco.viti@uni.lu
}

Received: 16 August 2020; Accepted: 9 September 2020; Published: 11 September 2020

check for updates

\begin{abstract}
Workplace relocation can have a significant impact on commuting trips as well as on the location and number of activities scheduled within the home-work tour. This often exogenous, non-voluntary event affects the entire activity-travel behavior of the employees. As response, employees can adopt several short- and long-term adaptation strategies to cope with such change, the most obvious being commuting mode shifting, acquire new mobility resources (e.g., buying a car) or changing residential location. As workplace relocation can be consequence of national policies aimed at decongesting the city centers or to favor the development of new business areas, undesired macroscopic changes in modal shares and in land developments may be observed. While a decrease in the commuting time after a workplace relocation is, in some cases, observed, an increase in car use for the commuting trip may be observed as well. This paper aims at providing an in-depth understanding of the effect of workplace relocation on travel behavior by reviewing and selecting the relevant scientific literature on the topic, which has in the last years gained popularity. The findings and observations summarized by the literature review are then complemented with the specific example of the relocation of the University of Luxembourg employees. Finally, we indicate potential directions for research, which are currently underexplored.
\end{abstract}

Keywords: workplace relocation; travel behavior; commuting; trip chaining; mode choice

\section{Introduction}

Workplace relocation can be a decision made by the employer to seek (expected) advantages for the company (lower rental costs, higher accessibility, opportunity for expansion, access to labor market, etc.) and to meet societal goals (contributing to less pressure on central business districts, development or requalification of peripheral areas, etc.). The global employee relocation market was valued at $\$ 29$ billion in 2017 and is forecasted to grow up to $\$ 32$ billion by 2021. Despite many key drivers that can guide the decision of where to relocate firms, rarely does this decision consider the impact on the mobility of the relocated employees.

Relocating the workplace is an important life event that has the potential to impact employees' commuting behavior as well as their entire daily mobility and habits, since often daily activities are chained to the home-work trip. Many studies indicate that workplace relocations are often associated with increased car commuting rates (e.g., [1,2]). Hence, urban planners or policy makers might wish to monitor and manage the mobility of firms in order to mitigate or, at least, anticipate possible 
negative effects in terms of sustainable mobility. This process may need a long transition period to push commuters towards more sustainable transport modes [3].

Residential relocation and change in the employment status are the two life events having the most impact on travel behavior [4,5]. Although these two life events are, in most cases, resulting from individuals' or households' choice, this is not always true for workplace relocation, hence some workers have no other choice than to develop adaptation strategies in order to cope with changes in their daily routine. To cope with office relocation, workers might adopt various short-, mid-, and long-term adaptation strategies [6]. Shifting to a different mode seems a rather intuitive adaptation response, but individuals might also change job, move residence, modify their habitual activity locations, modify their activity pattern (e.g., activity sequence, activity duration), acquire or adopt new mobility solutions, etc. [7].

The aim of this study is to systematically review and discuss studies that specifically focus on the impact of workplace relocation on travel behavior, and more specifically on mode choice, looking at both short-term and long-term effects. To complement the literature survey, we share our experience following the monitoring and recurring data collection and analysis of the University of Luxembourg relocation, which, in its comprehensiveness and complexity represents a perfect example to show quantitatively workplace relocation impacts. In this sense, this review is complementary to a recent work where the literature addressing and analyzing the impact of workplace location on travel behavior has been reviewed [8]. In line with earlier work, this study focuses on relocations as a decision from the employer (or due to some adopted policy) perspective, and not from the employee. This is rather common since most of workplace relocations do not result from individual decisions, unless this decision is made as response to changing the job. For a comprehensive overview of relocation of residence and job places as a choice made by individuals, the reader can refer also to the work of Van Ommeren [9].

Differently from previous works, the main objective of this paper is to provide a comprehensive analysis of the impact of workplace relocation on travel behavior, and to identify possible knowledge gaps suggesting future research directions. A second objective is to provide researchers with advice on which methodology (related to data collection, analysis, and comparison techniques) should be adopted depending on the investigated research question. Therefore, in Section 2 we begin with an overview of the different data collection strategies and methodological approaches adopted in past works to study workplace relocation impacts. Section 3 focuses on short-term impacts, in particular in the travel behavior. This is an extensively researched topic, which we enrich by discussing two relatively less explored aspects. First, we discuss the impact on the full daily activity-travel patterns, and in particular how job relocation can change the location and number of activities performed in the home-work trip chain. Second, we show that commuting travel surveys may not give the full picture if only data from the typical day is collected. We show in fact from our case study that atypical days can be very frequent, and the travel behavior and experience may be significantly different. Section 4 explores the longer-term dimension and in particular the effects of relocation to car ownership and residential choice. Finally, Section 5 discusses the implications of workplace relocation to develop and implement sustainable transport policies, and more generally to company mobility management strategies, and provides the main conclusions of this study.

\section{Workplace Relocation Impact: Some Background}

The impact of changing the job location may involve decisions at different levels and may depend on external and contextual characteristics. Figure 1 provides a graphical representation of the different variables involved and affecting mode choice, and modal shifts in case of relocations.

We can broadly distinguish four types of factors determining mode choice, related to characteristics of the workers, of the company, to the environment, and to the transportation services. Changes in individual/household characteristics may be exogenous and not influenced by changes in workplace location, like for instance the individual socio-economic characteristics (education, age, family 
composition), whereas income could be impacted (e.g., salary raise to compensate for the relocation). Vice versa, they could be factors that favor or discourage modal shifts (e.g., mobility impairments). Other factors such as car ownership or residential location can be long-term decisions that have been done in response (or sometimes in anticipation) to workplace relocation.

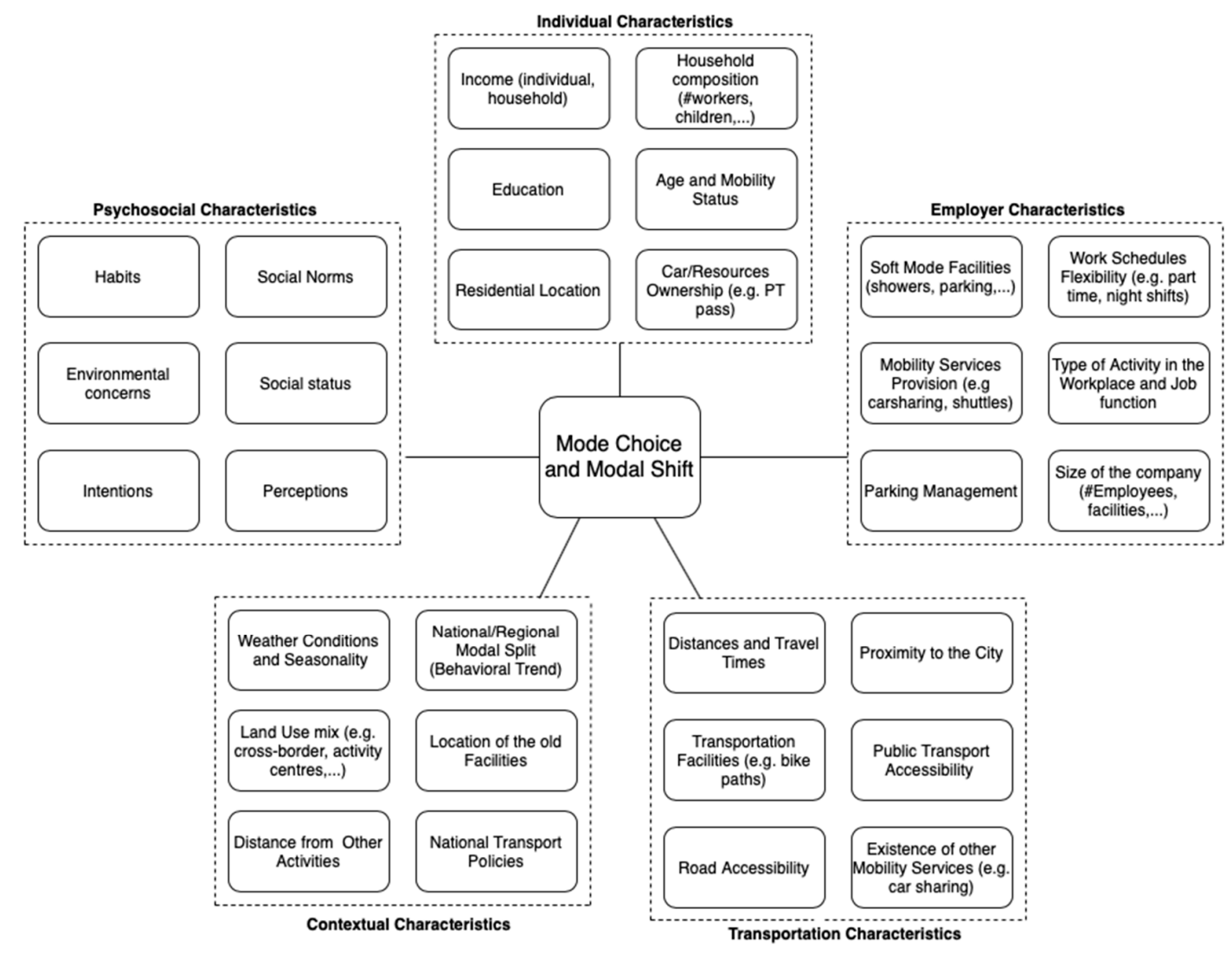

Figure 1. Main determinants of commuting mode choice.

Employer characteristics can also explain commuting mode shifts. In particular, providing or limiting facilities such as bike and car parking spots, corporate mobility services (carpooling, car-sharing) and generally mobility management solutions at the enterprise level have an impact on commuters' behavior, and these measures may be more effective depending on the size and type of business. For instance, large employers can enjoy the economy of scale of shared mobility, as well as flexible working hours and part time allow to reduce the number of trips to work. Similarly, improvements in the quality of the available transportation systems (road capacities, public transport and other collective services, bike paths, etc.) at the new site may partly explain changes in travel behavior, when compared to the situation at the old sites. Additionally, decisions can be different depending on the specific context and be driven by national trends (sustainable policies, land use development) or external events (weather conditions). Finally, psychosocial characteristics such as social norms and status, environmental concerns, habits, as well as intentions and perceptions may be determinants explaining differences in mode choices. We will not go in depth on these last characteristics and the reader can refer to the comprehensive review by De Witte et al. [10].

Following the scheme depicted in Figure 1, in this paper we analyze and discuss the literature investigating the relation between the above variables. To complement the literature review, we share our experience and the results of the University of Luxembourg relocation, which is used as case study. Being a very complex and interdisciplinary problem, involving human behavior and factors, transportation engineering, economics and spatial planning, providing a concise and coherent analysis 
is extremely difficult. Our approach does not pretend to be exhaustive, but to provide a number of points for discussion and to highlight potentially unexplored research directions.

This paper specifically focuses on the modification of the employees' travel behavior after their workplace relocation. Other stakeholders, such as recurrent business visitors or delivery companies may also have to adapt their mobility pattern to the new location [11]. Although it is a relevant category, we did not perform deeper analysis in this respect.

\subsection{Literature Selection Strategy and Overview of Selected Papers}

The available literature on workplace relocation is vast enough to discuss possible general trends, and to highlight the relevance of contextual specificities. In particular, we reviewed and classified works based on the types of data collected and analyzed (e.g., census data collected over multiple years, dedicated travel surveys, etc.), the study approach (single relocation study, analysis of a large number of firms, etc.), and the methodology adopted for the analysis (quantitative, descriptive, etc.). Moreover, general conclusions on the impact observed in terms of travel time, distance, and mode changes are synthetically summarized.

A large variety of keywords were used (i.e., employment decentralization, jobs suburbanization, offices relocation, etc.), combined with a variety of definitions related to mobility (i.e., travel behavior, commuting traveling, daily mobility, activity-travel patterns, etc.). Hence, it was not possible to use a structured paper selection approach (as suggested by e.g., [12]). Instead, a backward snowballing method was used to identify topical papers and extract the relevant results.

The effect of workplace relocation on commuting patterns became a main a subject of study since the 1960s [13-16] but this research question has mainly gained popularity in the 1990s (e.g., [17-22]) especially thanks to new data collection techniques (e.g., digital surveys). Geographically, case studies are reported for the US [18,23-27], Europe [1,7,13-17,19,22,28-31], Australia [32-34], and Asia [2,20,21]. Figure 1 shows the geographical spread of the studies considered in this literature review.

The selected papers for this study cover a long period of time (1966-2020) and have a broad geographical spread (see Table 1 and Figure 2 for an overview). In the 1960s, employment decentralization was the dominant spatial trend in American metropolitan areas and many studies focused on the impact of decentralized offices in the commuting mode choice [13,14]. Some of the reviewed scientific studies dealt exclusively with office decentralization but did not include information on the mobility aspects. Wabe [14] explained how "The location of Offices Bureau" was fostering companies to move from central London to the periphery. Yang et al. [2] provided another example of decentralization planned by national governmental policies using data from Kunming, China. The impact of massive workplace relocations (or Government Job Resettlement (GJR) using their terminology) from the urban center to new towns located at the periphery was studied. According to Aarhus [19], suburban areas become attractive as they may offer faster licensing procedures, planning or construction authorizations, and other administrative regulations. Concerning the drawback for institutions for moving from a central to a peripheral site, we can mention the loss of prestige and attractiveness, the possible longer distance from the "places of power," increased difficulty in reaching the institution's location for visitors, etc. 
Table 1. Overview and classification of selected papers.

\begin{tabular}{|c|c|c|c|c|c|c|c|}
\hline \multirow{2}{*}{ Publications } & \multirow{2}{*}{ Spatial Context } & \multirow{2}{*}{ Type of Data } & \multirow{2}{*}{ Study Approach } & \multirow{2}{*}{ Methodology } & \multicolumn{3}{|c|}{ General Conclusion on: } \\
\hline & & & & & Time & Distance & Mode \\
\hline Aarhus (2000) & Oslo, Norway & $\begin{array}{l}\text { Post relocation interview with } \\
\text { representatives of } 5 \text { companies }\end{array}$ & Single relocation & Qualitative analysis & NA & NA & Car increase \\
\hline Aguiléra et al. (2009) & Paris, France & $\begin{array}{l}1982 \text { and } 1999 \text { metropolitan } \\
\text { census data }+1983 \text { and } 2001 \text { Paris } \\
\text { travel surveys }\end{array}$ & Suburbanization trend & $\begin{array}{l}\text { Thorough descriptive } \\
\text { comparison }\end{array}$ & Stable & Slight increase & Slight car use decrease \\
\hline Alpkokin et al. (2008) & Istanbul, Turkey & $\begin{array}{l}\text { Workplaces' location in } 1985 \\
\text { and } 1997\end{array}$ & Decentralization trend & $\begin{array}{l}\text { Employment cluster } \\
\text { dynamics analysis }\end{array}$ & Decrease & NA & NA \\
\hline Angel and Blei (2016) & USA & $\begin{array}{l}\text { Workplace relocation of several } \\
\text { firms in } 40 \text { US cities }\end{array}$ & Decentralization trend & Descriptive analysis & Decrease & Decrease & NA \\
\hline Bell (1991) & Melbourne, Australia & Prior and ex ante travel survey & Single relocation & $\begin{array}{l}\text { Thorough descriptive } \\
\text { comparison }\end{array}$ & Decreased & NA & Car increase \\
\hline Burke et al. (2011) & Brisbane, Australia & $\begin{array}{l}\text { Regional travel survey, stated } \\
\text { preference surveys }\end{array}$ & $\begin{array}{l}\text { Decentralization trend } \\
\text { forecasting }\end{array}$ & $\begin{array}{l}\text { Modeling and Simulation } \\
\text { approach }\end{array}$ & low decrease & low decrease & PT increase \\
\hline Cervero \& Landis (1992) & San-Francisco bay area & $\begin{array}{l}\text { Survey on } 320 \text { former downtown } \\
\text { workers }\end{array}$ & Suburbanization trend & $\begin{array}{l}\text { Submarket analysis and } \\
\text { stepwise regression }\end{array}$ & Decrease & Stable & $\begin{array}{l}\text { car increase, PT } \\
\text { decrease }\end{array}$ \\
\hline Cervero \& Wu (1998) & San-Francisco bay area & $\begin{array}{l}\text { Vehicle miles traveled (VMT) } \\
\text { between } 1980 \text { and } 1990\end{array}$ & Suburbanization trend & Decomposition analysis & NA & increase & Car increase \\
\hline Cervero (1991) & USA & $\begin{array}{l}\text { Transportation and land use data } \\
\text { at the building level for } 6 \\
\text { suburban centers }\end{array}$ & $\begin{array}{l}\text { Suburban centres } \\
\text { analysis }\end{array}$ & $\begin{array}{l}\text { Stepwise regression and } \\
\text { elasticities analysis }\end{array}$ & NA & NA & NA \\
\hline Cumming et al. (2019) & Kelowna, Canada & Stated Preference Survey & $\begin{array}{l}\text { Single relocation (to } \\
\text { downtown) }\end{array}$ & Modal shift modeling & Decrease & Decrease & $\begin{array}{l}\text { Car shift to PT and } \\
\text { carpool }\end{array}$ \\
\hline Daniels (1970) & Greater London, UK & $\begin{array}{l}1961 \text { and } 1966 \text { national } \\
\text { employment census data }\end{array}$ & Decentralization trend & $\begin{array}{l}\text { Thorough descriptive } \\
\text { comparison }\end{array}$ & Large decrease & Possible decrease & Car increase \\
\hline Daniels (1972) & Greater London, UK & $\begin{array}{l}\text { Survey implemented in } 1969 \text { on } \\
63 \text { decentralized offices ( } 7143 \\
\text { respondents) }\end{array}$ & Several relocations & $\begin{array}{l}\text { Descriptive analysis and } \\
\text { linear regression }\end{array}$ & NA & NA & Car increase \\
\hline Daniels (1981) & Greater London, UK & $\begin{array}{l}2 \text { cross-sectional travel surveys } \\
\text { (1969 and 1976) implemented on, } \\
\text { respectively, } 7143 \text { and } 7760 \\
\text { workers) }\end{array}$ & Several relocations & $\begin{array}{l}\text { Descriptive analysis and } \\
\text { linear regression }\end{array}$ & NA & NA & Car increase \\
\hline Frater et al. (2019) & Christchurch, NZ & Focus group interviews & $\begin{array}{l}\text { Several relocations } \\
\text { from suburb to } \\
\text { downtown }\end{array}$ & $\begin{array}{l}\text { Analysis of Variance } \\
\text { (ANOVA) }\end{array}$ & NA & NA & $\begin{array}{l}\text { Car shift to PT, soft } \\
\text { modes and carpool }\end{array}$ \\
\hline Gerber et al. (2020) & Montreal, Canada & $\begin{array}{l}\text { Retrospective survey for before } \\
\text { and after relocation }\end{array}$ & Single relocation & Discrete choice modeling & Slight decrease & NA & NA \\
\hline
\end{tabular}


Table 1. Cont.

\begin{tabular}{|c|c|c|c|c|c|c|c|}
\hline \multirow{2}{*}{ Publications } & \multirow{2}{*}{ Spatial Context } & \multirow{2}{*}{ Type of Data } & \multirow{2}{*}{ Study Approach } & \multirow{2}{*}{ Methodology } & \multicolumn{3}{|c|}{ General Conclusion on: } \\
\hline & & & & & Time & Distance & Mode \\
\hline Gordon et al. (1989) & $\begin{array}{l}25 \text { largest urbanized } \\
\text { areas in USA }\end{array}$ & $\begin{array}{l}1977 \text { and } 1983 \text { Nationwide } \\
\text { Personal Transportation } \\
\text { Study survey }\end{array}$ & Decentralization trend & $\begin{array}{l}\text { Thorough descriptive } \\
\text { comparison }\end{array}$ & Decrease & NA & NA \\
\hline Gordon et al. (1991) & 20 American cities & $\begin{array}{l}\text { American Housing Survey data } \\
\text { for } 1980 \text { and } 1985 \text { for the } 20 \\
\text { biggest American } \\
\text { metropolitan area }\end{array}$ & Decentralization trend & $\begin{array}{l}\text { Aggregated commuting } \\
\text { behavior comparison }\end{array}$ & Decrease & Decrease & NA \\
\hline Hanssen (1995) & Oslo, Norway & $\begin{array}{l}\text { Prior and ex ante 1-day } \\
\text { travel diary }\end{array}$ & Single relocation & $\begin{array}{l}\text { Thorough descriptive } \\
\text { comparison }\end{array}$ & Stable & Increase & $\begin{array}{l}\text { car increase, } \\
\text { PT decrease }\end{array}$ \\
\hline Kim (2008) & Seattle area, USA & $\begin{array}{l}\text { Household panel data ( } 2 \\
\text { consecutive years) between } 1989 \\
\text { and } 1997\end{array}$ & $\begin{array}{l}\text { Co-location } \\
\text { hypothesis testing }\end{array}$ & $\begin{array}{l}\text { Descriptive comparison and } \\
\text { location choice modeling }\end{array}$ & Stable & Stable & NA \\
\hline Levinson \& Kumar (1994) & Washington DC, USA & $\begin{array}{l}\text { Detailed person travel survey for } \\
1968 \text { and } 1988 \text { in } \\
\text { Washington DC, USA }\end{array}$ & Decentralization trend & $\begin{array}{l}\text { Thorough descriptive } \\
\text { comparison }\end{array}$ & $\begin{array}{l}\text { Stable or slight } \\
\text { decrease }\end{array}$ & Increase & NA \\
\hline Li et al. (2016) & Brisbane, Australia & Traffic volumes & $\begin{array}{l}\text { Modeled Single } \\
\text { relocation }\end{array}$ & $\begin{array}{l}\text { Transport modeling and } \\
\text { Simulation approach }\end{array}$ & low decrease & low decrease & transit trip increase \\
\hline Naess \& Sandberg (1996) & Oslo, Norway & $\begin{array}{l}\text { Travel survey of } 485 \text { workers } \\
\text { from } 6 \text { institutions }\end{array}$ & Single relocation & $\begin{array}{l}\text { Multivariate Regression } \\
\text { Analysis }\end{array}$ & NA & Increase & Shift to car \\
\hline Olaru et al. (2004) & Melbourne, Australia & Focus group interviews & Single relocation & $\begin{array}{l}\text { Descriptive comparison and } \\
\text { quantitative analysis }\end{array}$ & Slight increase & Slight increase & $\begin{array}{l}\text { Decrease of soft } \\
\text { modes use }\end{array}$ \\
\hline Patella et al. (2019) & Rome, Italy & Focus group interviews & $\begin{array}{l}\text { Single relocation } \\
\text { (to downtown) }\end{array}$ & Discrete Choice Models & Decrease & Decrease & $\begin{array}{l}\text { Potential car } \\
\text { decrease/use of } \\
\text { Park\&Ride }\end{array}$ \\
\hline Rau et al. (2019) & Munich, Germany & $\begin{array}{l}\text { Quasi-longitudinal survey data } \\
\text { based on retrospection }\end{array}$ & $\begin{array}{l}\text { Single relocation } \\
\text { (to suburbs) }\end{array}$ & $\begin{array}{l}\text { Mobility Biographies } \\
\text { Approach }\end{array}$ & NA & NA & Shift to car \\
\hline Sim et al. (2001) & Tampines, Singapore & $\begin{array}{l}\text { Household survey }(\mathrm{N}=1797), \\
\text { Employees survey }(\mathrm{N}=439) \text { and } \\
\text { Employers survey }(\mathrm{N}=25) \text { in } \\
\text { Tampines area }(1998)\end{array}$ & $\begin{array}{l}\text { Suburban job park } \\
\text { assessment }\end{array}$ & $\begin{array}{l}\text { Thorough descriptive } \\
\text { comparison }\end{array}$ & $\begin{array}{l}\text { Potential } \\
\text { decrease }\end{array}$ & Potential decrease & Potential car decrease \\
\hline Sprumont et al. (2014) & Luxembourg & $\begin{array}{l}\text { Travel survey before the } \\
\text { relocation ( } 329 \text { replies) }\end{array}$ & $\begin{array}{l}\text { Modelled Single } \\
\text { relocation }\end{array}$ & Discrete Choice Models & Slight increase & Increase & Shift to car \\
\hline Sprumont et al. (2018) & Luxembourg & $\begin{array}{l}2 \text { weeks travel diary before and } \\
\text { after relocation ( } 51 \text { and } 43 \\
\text { individuals) }\end{array}$ & Single relocation & $\begin{array}{l}\text { Standard Deviational } \\
\text { Ellipses }\end{array}$ & NA & NA & NA \\
\hline Vale (2013) & Lisbon, Portugal & Retrospective questionnaire & Single relocation & Discrete Choice Models & Slight increase & Slight increase & Car increase \\
\hline
\end{tabular}


Table 1. Cont

\begin{tabular}{|c|c|c|c|c|c|c|c|}
\hline \multirow{2}{*}{ Publications } & \multirow{2}{*}{ Spatial Context } & \multirow{2}{*}{ Type of Data } & \multirow{2}{*}{ Study Approach } & \multirow{2}{*}{ Methodology } & \multicolumn{3}{|c|}{ General Conclusion on: } \\
\hline & & & & & Time & Distance & Mode \\
\hline von Behren et al. (2018) & Karlsruhe, Germany & $\begin{array}{l}\text { Face-to-face interviews before } \\
\text { and after relocation }\end{array}$ & $\begin{array}{l}\text { Relocation from } \\
\text { suburb to downtown }\end{array}$ & $\begin{array}{l}\text { Thorough descriptive } \\
\text { comparison }\end{array}$ & Slight decrease & Slight decrease & Car use decrease \\
\hline Walker et al. (2015) & Godalming, UK & $\begin{array}{l}3 \text { Surveys ( } 1 \text { before, } 2 \text { after) to } \\
\text { assess employees' mode habits }\end{array}$ & Single relocation & $\begin{array}{l}\text { Linear mixed-effects model } \\
\text { and logistic regression }\end{array}$ & NA & NA & $\begin{array}{l}\text { Train increase, } \\
\text { car decrease }\end{array}$ \\
\hline Wabe (1967) & London, UK & $\begin{array}{l}\text { Questionnaire on a firm } \\
\text { workforce ( } 600 \text { staff) } 2 \text { years after } \\
\text { the relocation }\end{array}$ & Single relocation & $\begin{array}{l}\text { Thorough descriptive } \\
\text { comparison }\end{array}$ & $\begin{array}{l}\text { Important } \\
\text { decrease }\end{array}$ & Possible decrease & Car increase \\
\hline Yang et al. (2016) & Kunming, China & $\begin{array}{l}\text { Stated Preference }+ \text { Revealed } \\
\text { Preference survey }\end{array}$ & Single relocation & $\begin{array}{l}\text { Discrete Choice } \\
\text { Models (MNL) }\end{array}$ & NA & NA & $\begin{array}{l}\text { From soft and PT to } \\
\text { car use }\end{array}$ \\
\hline
\end{tabular}

NA: Not Addressed; PT, public transport. 


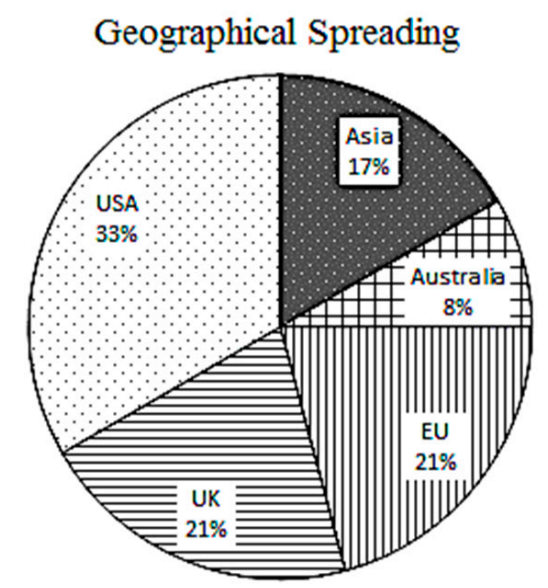

Figure 2. Geographical spreading of the selected studies.

Some studies $[18,22,25,26,35]$ describe the aggregated effect of employment suburbanization at the regional level using census data. Even if this is unlikely, job suburbanization trends might happen without the relocation of a single company. Creation of a new company in the suburbs, disappearance of business in the city centers might contribute to job sub-centering process. For instance, Aguilera et al. [22] using the metropolitan travel survey of Paris in 1983 and 1991, showed the effect of job-decentralization without analyzing specifically a company relocation. Studies using both approaches, i.e., either the analysis of job suburbanization trends or single relocation events, have been included in this literature review. Indeed, it is assumed that single decentralizations are, among other things, the cause of employment suburbanization trends.

\subsection{Case Study: The University of Luxembourg Relocation}

To enrich this literature review with evidence-based analysis, we used our experience with the University of Luxembourg relocation. This case study is exemplary, since it involves and allows us to discuss and provide empirical findings related to most of the determinants illustrated in Figure 1 , thanks to the availability of different dataset obtained over a long period (8 years) and using different data collection strategies and modeling techniques, which will be further introduced in Section 3 . Figure 3 provides a timeline of the major events determining the workplace relocation dynamics (national policies, moving phases, introduction of mobility services) on top, while at the bottom the different data collection campaigns are shown.

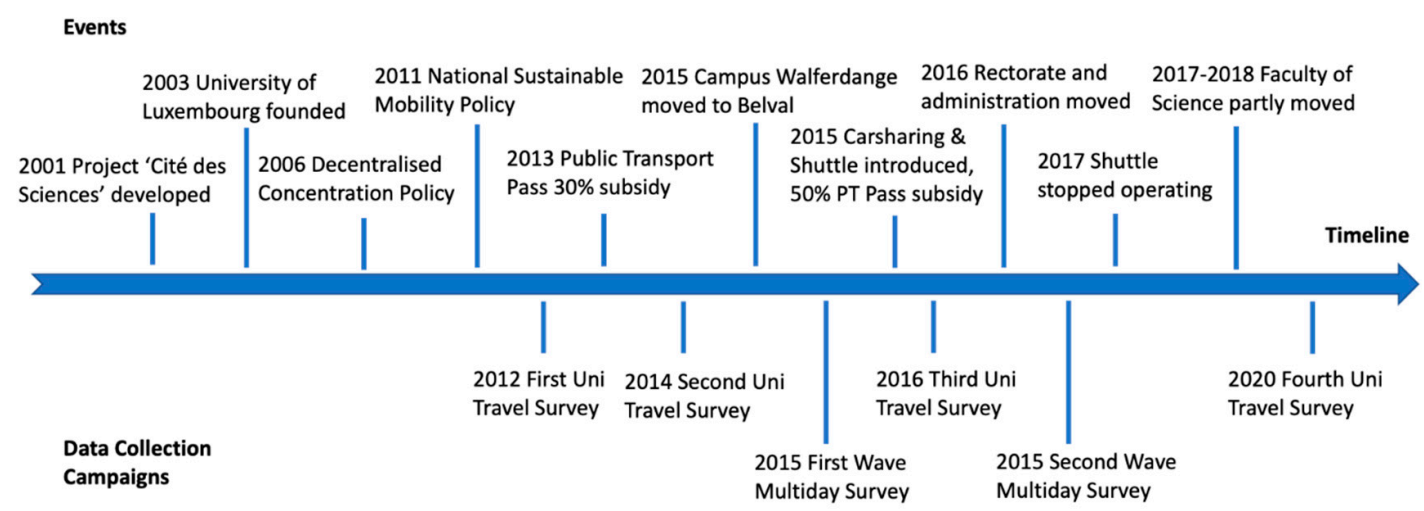

Figure 3. Timeline of the main events related to the University of Luxembourg relocation.

The University of Luxembourg is a young university welcoming 6500 students and more than 1800 staff members and is the only public university in the Grand-Duchy of Luxembourg, a small 
European country facing big mobility challenges. Every day, in addition to more than 250,000 generated commuting trips produced by the 626,000 residents, the country welcomes around 200,000 cross-border workers, which represent almost $43 \%$ of the total work force [36]. While $73 \%$ of the workers living in Luxembourg commute by car, the share reaches $85 \%$ for cross-border workers [37]. Despite being a car-dependent country, ambitious modal split targets have been adopted since almost a decade through a National Sustainable Mobility Plan, based on which, by 2025, 25\% of all trips should be performed using non-motorized modes of transportation (walking and cycling), while of the remaining $75 \%, 25 \%$ should be done by public transport (PT). These targets have also been differentiated by commuting distances [38].

The high congestion levels experienced in Luxembourg are related to the historical monocentric development of the country: approximately $50 \%$ of jobs are located in Luxembourg City. In order to decrease the pressure to the capital (in terms of commuting flow, residential prices, etc.), and to reach a more balanced development of the country, a decentralized concentration [39-41] land use policy has been implemented in 2006. One of the main projects following this policy is the creation of the Citéde Sciences in Belval, an area located in the South-West region of the country. This site, a former industrial area, hosts today most of the university facilities, research centers, company headquarters, a hotel, theatres, music hall, a train station, and various types of accommodation, especially for students and university staff. This new activity center is also expected to increase the attractiveness of the surrounding cities, favoring the expansion of the whole region. The University of Luxembourg started relocating to Belval from 2015. Formerly, the majority of the university activities were located on three campuses located in Luxembourg City (Kirchberg and Limpertsberg) or in its close surroundings (Walferdange). The Walferdange campus, hosting more than 600 employees, was the first to fully relocate, followed by two more waves in 2016 (the university administration) and in 2017 and 2018 with part of the Faculty of Science and Technology. To handle the transition period, with staff commuting almost daily to and from different campuses, the university adopted different mobility management measures to improve the accessibility of the campuses. In particular, in 2015 a corporate car-sharing system was introduced, together with an inter-campus shuttle (later discontinued due to high operating costs and low usage). Also, since 2013 public transport monthly passes have been provided with a discount, initially set to $30 \%$ and then raised to $50 \%$ from 2015 . To date, around $75 \%$ of the staff members currently have the main office in Belval, but daily interactions between campuses are frequently observed, especially for meetings and for lectures.

This relocation activity of the University of Luxembourg represented an excellent case study for analyzing short and long-term changes in mobility patterns and habits due to workplace relocation. For this purpose, four travel surveys collecting the commuting behavior of a minimum of $35 \%$ of the university staff were performed $(2012,2014,2016$, and 2020). In addition, two waves of a 2-week travel diary were collected in 2015 and 2016 with a sample from the staff members of the Walferdange campus, in order to obtain additional insights into the whole activity-travel behavior of the relocated staff. Some in-depth analyses performed with this data were published in earlier papers [7,31,41], and main results are used in this paper to showcase and support the findings from the literature survey, and to provide empirical and evidence-based arguments for exploring further research opportunities.

\section{Data Collection and Methodological Approaches}

\subsection{Data Collection Strategies}

Analyzing job relocation trends requires, first, to have comparable databases collected at two or more collection periods. Choosing the correct interval of time is however not straightforward since a too short period may not allow long-term changes to be observed, whereas a too long period may result in observing changes caused by relocation with more general societal trends. For instance, Cervero and $\mathrm{Wu}$ [18] used data (size and density) from employment centers in the San-Francisco Bay Area in both 1980 and 1990 to generate and then analyze journey-to-work statistics. Similarly, in order to analyze 
the workplace location dynamics in Istanbul, Alpkokin et al. [35] used employment data in 1985 and 1997, while Gordon et al. [24,25] used data from the American Housing Survey of 1980 and 1985 for the twenty largest American metropolitan areas, hence providing general analyses at a nationwide level. Many studies such as $[11,17,19,23]$ used different data collection approaches. Bell [6] used prior and ex-ante cross sectional surveys to assess the impact of a workplace decentralization in Tooronga, Australia. Cervero and Landis [23] identified and selected workers whose jobs had been relocated from downtown to the suburbs and asked retrospective questions about their travel behavior before relocation and questions about their behavior after the move. Similarly to [6], Hanssen [17] collected travel behavior information before and after the event using a one-day travel diary.

An important time interval between two data sets allows to observe mid- and long-term effects of a relocation, but ongoing general trends might also affect the assessment of the firm relocation $[15,16,42,43]$. Daniels $[15,16]$ explains that while significant increases in car ownership rates were observed 8 years after companies decentralization, this associated to general car ownership trends in the UK during the 1960s and the 1970s. Levinson and Kumar [44], who used travel survey data of 1968 and 1988, mention that this rather long period was also characterized by "Metropolitan trends" (car ownership increase, population and travel demand increase, etc.) and also by important transportation infrastructure developments.

Implementing a data collection phase before and after the relocation can also lead to response rate issues. As pointed out by Sprumont et al. [7], a large time gap between the before and after data collection might have several drawbacks. First, some workers may have meanwhile decided to quit their job, other might have decided to relocate their house or other anchor activities (children's school location, preferred shopping places, etc.). These mid- and long-term adaptations might interact with short-term adaptations. Bell [6] implemented an ex-ante survey 5 months before the relocation and a second survey was implemented 10 months after the relocation (15 months' time between prior and ex ante surveys). In this study, constituted of 846 valid replies, only $50 \%$ of respondents were in common if compared to the first wave. Daniels $[15,16,42]$ performed a data collection campaign 8 years after implementing a first survey. It turned out that only $27 \%$ of the workers who participated to the first data collection phase also took part in the second phase. In addition, some employees' companies did not understand how they could contribute to the survey since they had been recruited years after the settlement of the firm to that actual location [42]. Wabe [43] also faced issues while collecting data from a firm (600 employees in total) 2 years after it moved from the London CBD to the suburbs. Indeed, no information was available regarding the share of workers who had quit the company in the meantime. Assessing the effect of workplace relocation after a large time interval might be tricky in the sense that some firms might not consider themselves as decentralized [42].

The adopted data collection method is an equally important aspect if compared to the number and frequency of times a survey campaign is performed. Stated preference surveys are a classical method to obtain information on travel behavioral changes (mode choice, change in individuals' socio-demographic characteristics, etc.). Yang et al. [2] used stated preference surveys to assess the impact of Government Job Relocation (GJR) in Kunming, China. They acknowledged the possibility that respondents, when filling the stated preferences experiment, may have chosen hypothetical travel modes without realizing all the implications for the data analysis (travel time, access to public transport services, etc.). Aarhus [19] opted instead for a focus group analysis with representatives of five companies in Oslo (Norway). This approach provided valuable information about the determinants of location selection of relocating companies, but did not provide precise information on modal split variations, commuting times or distance increases, etc. Walker et al. [45], when studying the relocation of a pro-environmental charity institution (WWF) in the United Kingdom, adopted a very interesting strategy, which consisted on collecting information 19 months prior to the relocation and then 1 and 4 weeks after the move. This peculiar data collection was implemented in order to test behavioral attitudes related to travel mode selection. Specific data were collected such as the Environmental Attitude Inventory (EAI) and a Self-Report Habit Index (SRHI). Sprumont and Viti [41] also developed and implemented a similar sophisticated data gathering process. One month before and one year 
after the relocation, they implemented a travel diary data set on 51 employees. For 2 weeks (including weekends) respondents provided information on all their activities (location, activity type, duration) and trips (time, mode), hence giving useful information on complete activity-travel chains. In addition, a stated preference survey was also collected using the same individuals to enrich the dataset with socio-demographic and other travel behavior-related data. Asking retrospective questions about travel behavior before a workplace relocation combined with questions regarding the behavior after the move seems good trade-off between data quality and time investment, as it was done recently by Gerber et al. [46]. However, depending on the timing of the data collection phase, results provided by retrospective questions might be distorted by time. This issue was already raised by Wabe [43], who highlighted that when asking for the commuting time at the previous workplace some inaccuracies might arise. Finally, access to human resources data allows to analyze other dynamics such as residence location of previously employed and new employees. These data have been also used in this paper to link our literature review to the specific case study.

Obviously, the data collection strategy to adopt depends on the research question and has to be developed carefully. Assessing the impact of an event, workplace relocation in this case, means that sufficient data collected both before and after the event will be needed, which causes additional complexity in the research process, and a challenge in collecting large, statistically significant datasets.

\subsection{Methodological Approaches}

The methodology for travel behavior analysis varies according to the research question. Studies covering most of the aspects of commuting pattern modification (commuting mode, distance, and time) due to workplace relocation mostly rely on thorough descriptive analyses (e.g., $[6,15,16,42,43])$. This allows researchers to adopt data-driven approaches such as linear or multivariate regression methods [11,45]. As an alternative, travel behavior modeling can leverage the data and provide additional interpretation and prediction opportunities. For example, Vale [1], Yang et al. [2], and Gerber et al. [46] used discrete choice models (Multinomial Logit, MNL) with revealed and stated preference data to compare the variation of parameter estimates between anticipated and actual mode choice. Sprumont et al. [31] used MNL to forecast future modal shifts at the new workplace using travel survey data prior to workplace relocation. Similarly, but at a larger scale, Li et al. [33] and Burke et al. [32] predicted different decentralization scenarios for 2031 at the city level using transport modeling techniques to estimate aggregated modal shares, vehicle kilometers and vehicle hours travelled. This long-term forecasting approach allows to analyze and test various policy regulations to mitigate the possible drawbacks of workplace decentralization.

In order to analyze decentralization impacts, Alpkokin et al. [35] used employment dynamic clustering analysis. Walker et al. [45] applied methods from psychology to analyze travel habit formations and decays during workplace relocation. They used data from Environmental Attitude Inventory (EAI) and a Self-Report Habit Index (SRHI) to develop a linear mixed-effects model to compare habits strength for the new and old location and logistic regression to predict travel mode change. In order to assess the employees' activity space variation after a workplace relocation, Sprumont and Viti [41] used Geographical Information System (GIS) tools and more specifically Standard Deviational Ellipses (SDE) to assess the variation of the activity space related to a disruptive event in the activity-travel routine. Notably, this approach allowed to gain additional insight into the impact of relocation to the whole daily and weekly activity-travel behavior of the employees.

Obviously, no methodology is arguably better than another and, often, different methodologies may be applied to common datasets. The research question will suggest a specific methodology, which will likely influence the data collection strategy. A narrow, very specific research question can lead to specific data gathering processes and less conventional methodological approaches. 


\section{Short-Term Impact of Workplace Relocation}

\subsection{Workplace Relocation and Changes in Commuting Mode}

Modal shifts related to workplace relocation can be related to modifications of (1) the Public Transport (PT) accessibility, (2) the road accessibility, (3) the parking provision, and (4) the share of employees with a short distance to work [16]. Of course, a relocation from the city center to the suburbs has the potential to affect all of the aforementioned 4 elements.

The modal split variation is partially due to a modification of the distance to the Central Business District (CBD) and the urban density [24]. Bell [6] showed that after a decentralization from Melbourne downtown to a suburban area $8.5 \mathrm{~km}$ away from the CBD, car use increased from $34 \%$ to $76 \%$. Hanssen [17], using data from Oslo, indicated that the suburbanization of an insurance company increased car use from $25 \%$ to $41 \%$ despite that the new worksite was well served by public transport. More significant modal shift observations were provided by Wabe [43], who indicated that a firm decentralization in London led to an increase in car use from $8 \%$ to $71 \%$. However, as pointed out by Yang et al. [2], the relocation of the employees is not necessarily leading to higher car use. Indeed, many studies show that relocation or decentralization of firms is indeed often associated with higher car use levels $[6,15,16,42,43]$. However, counter examples can be found e.g., in the studies from Walker et al. [45] and Sim et al. [21], who mention a (possible) modal shift towards sustainable alternatives (mainly, from car to PT).

For the University of Luxembourg, changes in mode choices were very different from those forecasted by discrete choice models [31] when forecasting the effects of relocating to Belval (Table 2). A predicted increase of car use was not confirmed by the data, and, on the contrary, it decreased substantially in favor of a higher share of public transport trips. This may be due to the changes in transportation infrastructure and services, together with mobility management measures that were meanwhile adopted to guarantee a better accessibility to the new campus (new public transport lines, paid vs. free parking at the old campuses, public transport pass subsidies, introduction of a corporate car sharing system), together with long-term factors that are more difficult to be incorporated in travel prediction models (residential changes, company workforce turnover).

Table 2. Modal split at the University of Luxembourg collected with four travel survey waves.

\begin{tabular}{ccccc}
\hline & $\mathbf{2 0 1 2}(\mathbf{\%})$ & $\mathbf{2 0 1 4} \mathbf{( \% )}$ & $\mathbf{2 0 1 6}(\mathbf{\%})$ & $\mathbf{2 0 2 0}(\mathbf{\%})$ \\
\hline Soft Modes & 9 & 6 & 5 & 12 \\
Bus & 21 & 19 & 28 & 20 \\
Car & 51 & 54 & 44 & 47 \\
Train & 20 & 22 & 23 & 21 \\
& $100 \%$ & $100 \%$ & $100 \%$ & $100 \%$ \\
\hline
\end{tabular}

Often, people tend to stick to a commuting mode they are familiar with, as long as the commuting time remains below an acceptable threshold, hence showing mode selection habits [1]. This travel mode inertia explains why, using data from Lisbon (Portugal), $73.3 \%$ of employees facing an office decentralization did not opt for a new mean of transport. In order to keep (or achieve) important share of public transport users after a relocation, the provision of good transit service at the new location is of paramount importance. However, Transit Oriented Development (TOD) with good public transport provision is not guaranteed to lead to lower share of car use among the commuters [17]. On the other hand, free parking and good road accessibility can be important car incentives jeopardizing TOD goals. Indeed, compared to the CBD, suburban locations often enjoy a less congested road network. Moreover, due to cheap land availability, the provision of free parking spots is often a reality in suburban working sites and the less congested road conditions play a role as well. Cervero [47] confirmed that, at least for the American context, suburban areas are also associated with free parking (because of cheap land availability) and poor public transport connections. Hanssen [17] showed that after a company move 
from the center to the suburb the share of public transport users having to make one or more transfers increased from $8 \%$ to $28 \%$. Hence, the employment suburbanization is sometimes leading to a less favorable public transport accessibility.

Interestingly, Walker et al. [45] found that travel habits weakened immediately after a workplace relocation regardless if the employees shift to a new mode or not. Habits of workers who opted for a new mode did not disappear brutally but slowly decayed after the post-move period and during a period of 4 weeks. A disruptive event such as a workplace relocation is hence a good opportunity to foster modal shift but according to [45] this "window of opportunity for change" can also be seen as a "window of vulnerability to relapse." After a workplace decentralization, Bell [6] observed that car started to be seen as a "faster, more reliable, less expensive, more comfortable, cleaner and more convenient" commuting mode. If a certain share of workers shifts from, for instance, public transport to car, this could partly explain why, in some job decentralization studies, the commuting distance increase but the commuting time remains roughly constant [1].

Due to the enormous possible impact on travel behavior, numerous studies were undertaken to understand the aggregated effect on commuting time, distance, and mode. Workplace decentralization may not necessarily imply increasing commuting distances. Whereas some studies reported longer commuting times and distances (e.g., [11,22,24,25,43], others found commuting distances to reduce as locations may get closer to the residential areas. Angel and Blei [48] reported from a study involving 40 cities that average commuting distances were 1.6 times shorter than commuting to the CBD. This is in line with the co-location concept introduced by Gordon et al. [24], which posits that companies may select suburban locations in order to locate themselves closer to their employees, who had slowly moved to the suburb. Kim [49] provided an interesting study on the effect of co-location on commuting time stability and mentions that "little evidence contradicts the co-location hypothesis." Despite a probable shortening of the commuting time, the overall environmental impact appears to be dramatic. Indeed, despite the intense debate on the co-location hypothesis regarding the commuting time or distance there is little doubt regarding the significant car use increase. Levinson and Kumar [44] or Gordon et al. [24] also underlined the fact that dispersed or polycentric metropolitan structures are associated with shorter commuting times. Regarding the commuting time, Wabe [43], analyzing the London area data, observed that after a company suburbanization, the average commuting time of the employees was halved. The good road conditions and the massive shift towards car use are an explanation for this important commuting time decrease [32]. Similarly, as observed in the Australian context, the decrease in the home-to-work time would be partially due to the non-congested road network state for reverse commuting (from the center to the suburbs) [33]. Cervero and Landis [23] proposed interesting workers submarket analysis and indicate that if the aggregated commuting time was decreasing due to switch to faster mode and stable commuting distance this situation was not verified for all types of residential areas. In analogy to [22], Cervero and Landis [23] showed that, for instance, reverse commuters (e.g., downtown resident whose new workplace is in the suburbs) were facing an important increase of their commuting time and distance.

\subsection{Activity Pattern Modification and Changes in the Daily Mobility}

When analyzing the commuting behavior, often studies focus on the commuting trip. This may provide a short-sighted vision of the impacts of workplace relocation for two reasons. First, commuting represents only 1 out of 3-4 trips performed on average by an individual, and chained activities, performed during the day, may equally affect commuting mode choice (e.g., business trips, picking up or dropping off children, etc.). Second, travel behavior may differ significantly across weekdays, making it difficult to really capture the temporal variability of mode choices.

Workplace relocations are affecting the commuting trip characteristics (road and PT accessibility, parking provision, commuting distance) and when the home-work-home trip is routinized, the entire daily activity pattern is also affected. Moving may be associated with a change in the lifecycle stage and household scheduling. Aguilera et al. [22] showed that job suburbanization was associated with a 
decrease in the number of daily journeys performed by working central city residents. Bell [6] showed that relocating a workplace to an isolated new site can have important impact on the daily activities performed. In total, the workplace relocation led to a $10 \%$ decrease in the number of activities performed during a day (from 2.2 to 2 activities). The modification of the activity pattern is the example of a short-term adaptation due to a workplace decentralization. Bell [6] shows that the number of shopping activities performed per day decreased from $23.8 \%$ to $15.2 \%$.

Sprumont and Viti [41] showed that, after the relocation of the Walferdange campus, most of the activity locations close to the former working site that were previously visited were not re-visited after the relocation. This is showcased in Figure 4, where the location of all activities visited by three individuals, each representative of the three distinct clusters of staff members derived from the data analysis (see [41] for more details), is presented, together with their resulting Standard Deviational Ellipse (SDE), which geometrically and synthetically represents the spatial coverage of the activity locations. In this theory, home and work locations are seen as anchor points, and the ellipses delimit the space where individuals can seek for the locations of the other (chained) activities. The figure reveals that not only a large number of activity locations changed once the employee workplace has been relocated, but also the number of performed activities in a working day changed. By performing this analysis, Sprumont and Viti [41] concluded that the national objective, which was meant to decrease pressure (in terms of trips mainly) from Luxembourg city, was achieved also because only very few respondents still had activities close to their former working place.
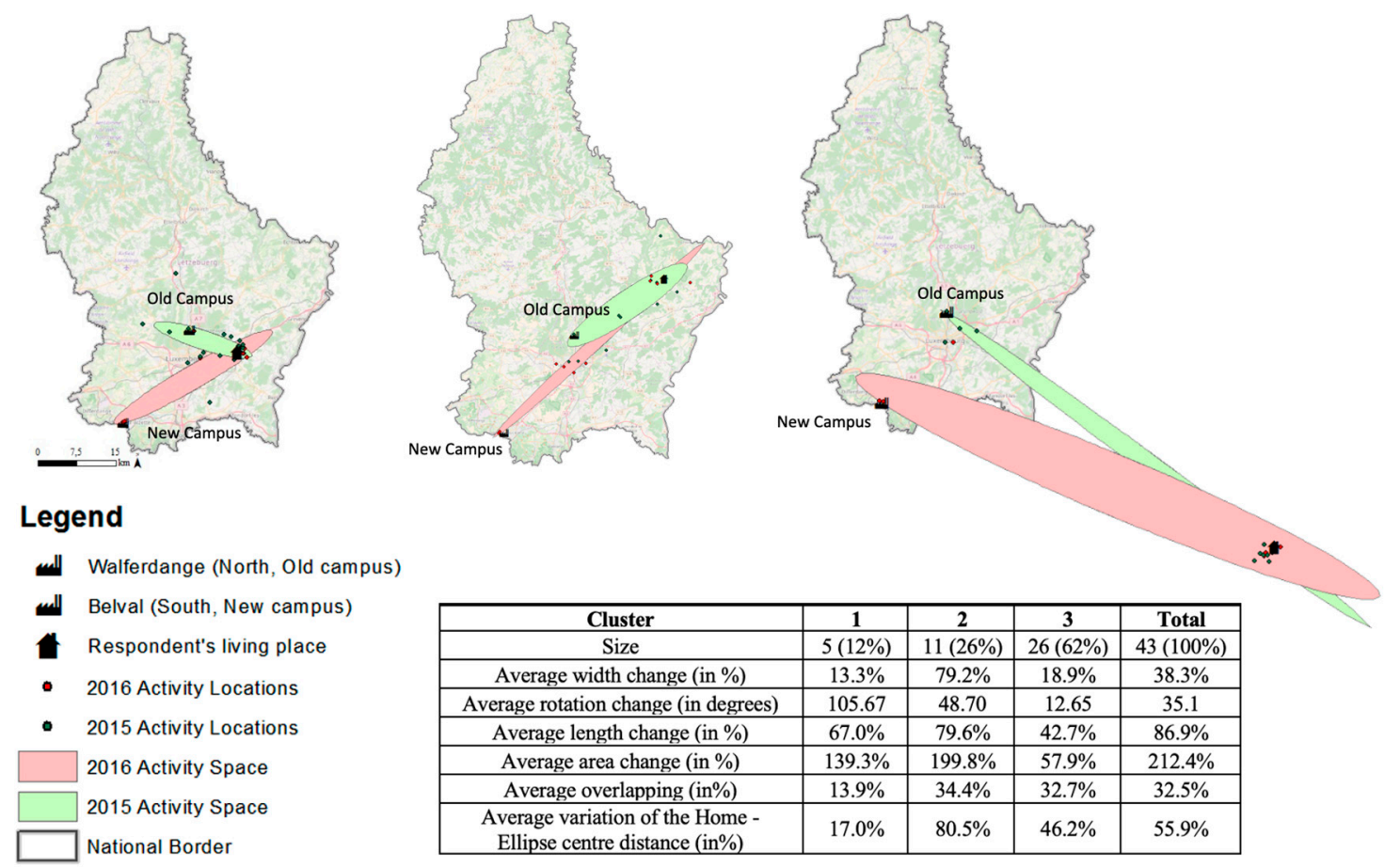

Figure 4. Daily activity locations, home and work location of three representative employees.

Apart from the influence of workplace relocation to chained activities, mobility habits may be affected because of new induced trips, or because the daily routine of an employee may significantly differ from one day of the week to another. In this sense the literature on workplace relocation we found misses to provide sufficient evidence and therefore it may be an opportunity for future research. Its relevance is demonstrated by the results of the 2020 Travel Survey of the University of Luxembourg, where it was asked for the first time to report a non-typical day, if this was occurring non-sporadically. Interestingly, $42.4 \%$ of the respondents stated to have a non-typical day, and $66 \%$ of these respondents indicated to perform this alternative commuting pattern at least once a week. Table 3 shows how typical and atypical days may differ in terms of commuting behavior. Notably, non-typical days are 
characterized by a lower number of modes used over the day, in accordance with a higher car usage and a higher number of activities chained to the commuting trip.

Table 3. Comparison of typical vs. atypical days.

\begin{tabular}{lll}
\hline & \multicolumn{1}{c}{ Typical Day } & \multicolumn{1}{c}{ Non-Typical Day } \\
\hline Average commuting time (min) & $43 \mathrm{~min}$ & $52 \mathrm{~min}$ \\
\hline Average number of modes used & 2.1 & 1.6 \\
\hline Modal split & $\begin{array}{l}38 \% \text { car, 51\% public transport, } 11 \% \\
\text { soft modes }\end{array}$ & $\begin{array}{l}47 \% \text { car, } 44 \% \text { public transport, } \% \\
\text { soft modes }\end{array}$ \\
\hline Satisfaction & $50 \%$ are satisfied or very satisfied & $37 \%$ are satisfied or very satisfied \\
\hline Activities on the way & $14 \%$ reported at least one activity & $19 \%$ reported at least one activity \\
\hline
\end{tabular}

Another interesting finding, when collecting information about atypical days, is that stated satisfaction may be very different for those days. As welfare and satisfaction have been recently deemed fundamental metrics for company's performance and employees' productivity and attachment to the employer [50], and it has been more extensively researched in the last years also in the context of workplace relocation (e.g., $[7,46])$, it will be relevant in future studies to draw more attention to collecting different mobility habits beyond the single commuting trip, and to identify those critical aspects that affect commuting satisfaction.

Focusing in particular on the role of atypical days, this may partly explain the changes in commuting satisfaction after workplace relocation, as reported in Figure 5. Since in 2020 the survey included the option 'Neither satisfied nor dissatisfied' a fair comparison of the results could not be performed and hence the 2020 results have been separated from the other three survey results. Figure $5 \mathrm{a}$ shows how commuting satisfaction had changed overall during the first part of the relocation phase, and in particular how the share of satisfied and very satisfied commuters had reduced in $2016(60 \%)$ with respect to the previous years (69\% and 63\%, respectively, in 2012 and 2014), when campus Belval was populated by a minor share of employees. In 2020 (Figure 5b), the satisfied and very satisfied commuters have notably reduced ( $48 \%$, probably also due to the high number of 'neutral' respondents), but this number is even lower when looking at the atypical days (37\%).

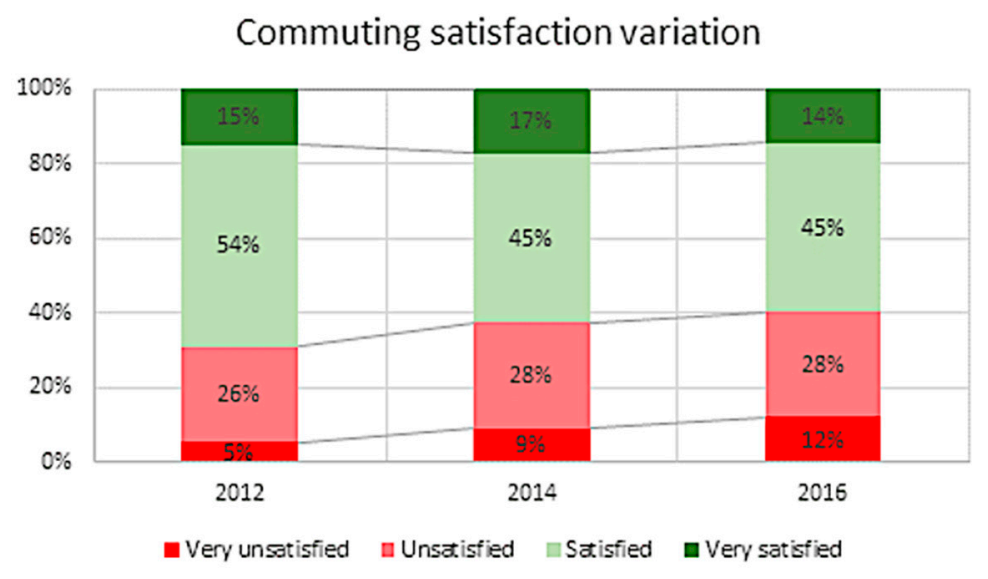

(a)

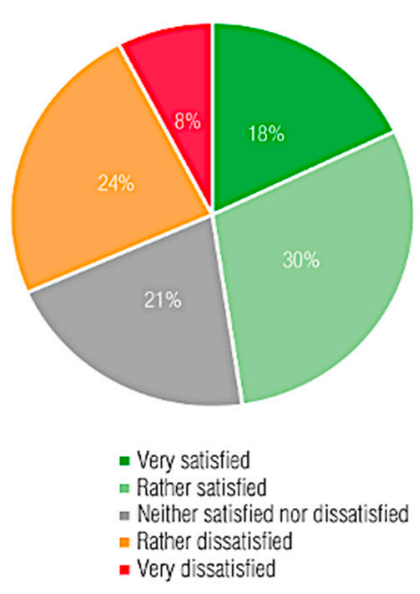

(b)

Figure 5. Change in stated commuting satisfaction according to the four survey campaigns in 2012, 2014 and 2016 (a), and in 2020 (b). 


\section{Long-Term Impact of Workplace Relocation}

\subsection{Car Ownership}

The increase in car ownership due to a workplace relocation or a job decentralization has rarely been the main focus of research studies. Notwithstanding, each time it has been analyzed, the workplace relocation has been associated with higher car ownership. However, the low number of studies and, sometimes, long time intervals affected by existing ongoing national trends do not allow any clear generalization [44].

Bell [6], analyzing the relocation of a major company in Melbourne (Australia), observed an increase in car ownership after the decentralization of the workplace. Indeed, a decrease (from $28.9 \%$ to $24.8 \%$ ) of households owning only one car was reported, and the post-relocation travel survey revealed that $8.2 \%$ of the respondents bought a car because of the new work location. Hanssen [17] reported how in a Norwegian held study an increase of car possession of $10 \%$ was measured among the employees, after a workplace decentralization of $20 \mathrm{~km}$.

Regarding car ownership variation after company relocation, Daniels [16,42] observed that, while between 1969 and 1976 household car ownership of employees at the decentralized office increased from $72.4 \%$ to $79.7 \%$, this was possibly related to a general ongoing national trend rather than a direct effect of the workplace decentralization. Levinson and Kumar [44], when analyzing the impact of the job decentralization pattern in Washington DC between 1968 and 1988, also faced similar issues. Indeed, for this specific area the number of cars per person increased from 0.48 to 0.73 and household car ownership increased from 1.6 to 2.0.

For the University of Luxembourg case, we observed rather counterintuitive trends, when comparing the statistics of the four travel surveys. In fact, in 2012 the car ownership of the staff members was $66 \%$, well below the national statistics, while it became consistent with national trends (around 76\%) in the following three surveys. This may be related to the moving to Belval, since people expected to have a poor public transport connection to the campus. However, this is not consistent with the observed mode choice, since, as shown previously in Table 2, car trips have reduced from 2012 to 2020. Hence, we cannot reliably explain these changes in trends, which may be also affected by company turnover (see Section 5.3).

\subsection{Residential Choice}

Vega and Reynolds-Feighan [51] point out that a strong correlation exists between residential suburbanization (also associated with higher car use levels) and the employment decentralization process, as residence and workplace location choice are often jointly determined [52]. Thus, a workplace relocation (imposed by the employer) can affect the relationship between the commuting mobility and residential choices. A study focusing on the relocation of the CSIRO Atmospheric Research laboratory from Aspendale to Clayton, two locations distanced $13 \mathrm{~km}$ from each other in Victora (Australia), indicated that families living in the immediate proximity of Aspendale and families with children will need to change considerably their trip chaining and repartition of daily activities. This may lead to relocation decisions or changes of jobs if their travel time precludes meeting family commitments [53].

On working days, home and work locations can be seen as anchor points determining the whole daily mobility patterns. This is at the foundation of location choice theories and analysis methods such as the SDE method used in Sprumont and Viti [41] and presented in Section 4.2, and in many other studies in the domain of Geography and Spatial Planning (e.g., [54]). However, in these works focused on individuals whose residential location remained unchanged. In [41], in total eight individuals $(18.6 \%)$ relocated their house, but not necessarily because of the workplace relocation.

Changes in residential locations observed in travel surveys can be also caused by a strong company turnover, which may be only partly related to workplace relocation (employees quitting because of commuting travelling dissatisfaction). This is for instance the case of the University of Luxembourg, where turnover especially of $\mathrm{PhD}$ students, but also the sensible growth of the number of staff members 
may explain the dynamics of changes in residential locations, as shown in Figure 6. This figure shows the change in number of university staff by municipality in between 2011 and 2014. As one can notice, a higher number of workers in 2014 is observed in the South-West side of the country, i.e., nearer to the new campus. It should be highlighted that the first relocation involving a significant number of employees occurred in 2015, hence this picture may suggest that, irrespectively whether the variations are attributable to newcomers or 'old' employees, residential location is a strategic choice that is influenced by workplace relocation. Therefore, acquiring insight into the reasons and the temporal characteristics of employees relocating their home, and relate them to workplace relocation characteristics (e.g. commuting distances and travel times, poorer connectivity and accessibility, etc.) may be an interesting research question that has not been fully addressed.

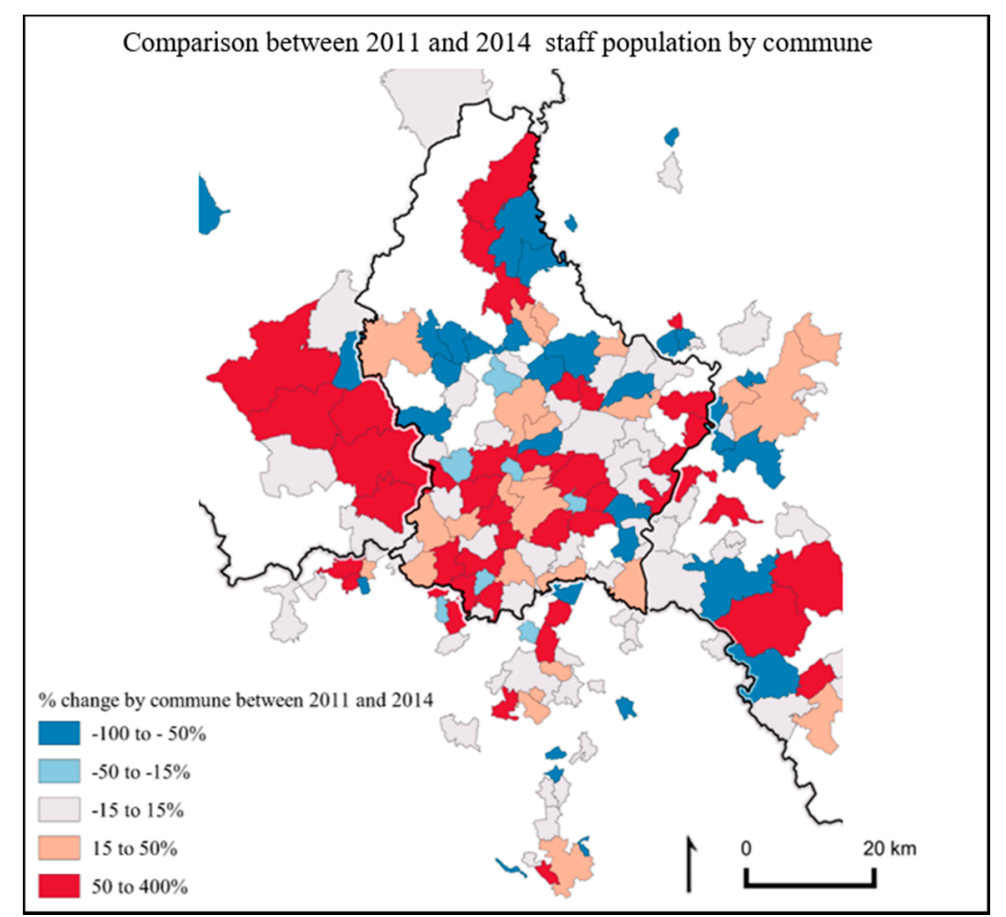

Figure 6. Change in number of residents by municipality between 2011 and 2014 .

While residential relocation due to a suburbanization of the working location is assumed to be a rather long-term decision, Bell [6] indicated that 10 months after a workplace relocation $15.4 \%$ of respondents to the prior survey indicated a change of residence; however, only $2 \%$ claimed that this decision was directly related to the new workplace location. Ten months after the move, Bell [6] observed a modification of the spatial pattern of the employees' living place. As mentioned by Naes and Sandberg [11], in the long term, residential changes among the employees and staff turnover did not balance the immediate increase in home-to-work distances due to the workplace relocation.

Hanssen [17] collected a one-day travel diary before and after the workplace relocation and did not find important changes in the residential location of the employees. As opposed to [6], it is possible that Hanssen [17] did not find any residential relocation trend because of the small distance between the old and the new workplace (the study considered a $6 \mathrm{~km}$ relocation between the old and the new workplace, for a major insurance company counting 1200 employees).

According to the co-location hypothesis $[24,25,44,49]$ the average commuting time has either remained constant or decreased in large American cities since the 1970s due to a location adjustment of both firms and households. Gordon et al. [25] mentioned that both firms and households moving towards suburban areas "do a very nice job of achieving balance and keeping commuting times within tolerable limits without costly planning interventions." Cervero and Landis [23] showed that workers 
whose employment has been relocated to the suburbs might decide to follow their job and relocate their house.

\subsection{Workforce Turnover}

When working with prior and ex-ante workplace relocation cross-sectional surveys, differences in aggregated modal split are presented (e.g., [6]). However, by using this data collection approach, information on workers whose contract ceased between the two data collection phases is unknown.

Daniels [42] indicated that only $27 \%$ of the employees who participated to the first data collection phase also took part to the second phase. So far, little is known regarding the magnitude and the reasons for this behavior. Of course, some natural reasons without link to the relocation (contract ending before the relocation, better job opportunity) might explain some departures. This is roughly in line with [49], who indicated that in many European and US cities, annually, approximately $20 \%$ of employed workers changed workplaces within the same metropolitan area.

Some workers, because of a particular lifestyle or specific mode choice attitude [55], may prefer a job-position downtown (or oppositely in the suburbs) [6]. Then, a workplace suburbanization might affect workers differently because of their mode preferences or lifestyle. While a workplace relocation can be related to higher car use levels among the concerned workforce, new hired employees (possibly locally to the new worksite) could have different modal split statistics with lower car use level [17]. However, Daniels [16,42] contradicts this assumption and highlights that staff replacement and new recruits did not lead to lower car use levels even 8 years after the company relocation. Wabe [43] raised an important issue regarding the employees' status and their adaptation regarding the company relocation. Consultants, who can represent an important share in engineering or IT companies, might be totally neglected by studies analyzing the effect of workplace relocation on firms' workforce. Firstly, consultants or sub-contractors may not be considered in the data collection phase targeting the company employees. Secondly, these specific worker categories often have complex residential and commuting mobility patterns due to the specificity of their position.

We could not unfortunately get reliable information regarding turnover dynamics for the University of Luxembourg case study. However, in the 2016 travel survey, $60 \%$ of the respondents were already working on the Belval campus. To these people it was asked if they previously had worked on another campus. Interestingly, $71 \%$ (254 people) were previously working on another campus and among them around 50\% (113) indicated that they adopted new travel habits. Only a minority purchased a car (9 people) or relocated their living place (15 people). Also, one-sixth of the respondents (41 people) working previously on another campus acquired a public transport pass after the relocation. However, concerning these long-term adaptations, it is very difficult to prove if they are directly caused by the relocation, since they are choices that may be done as response to other life events (having a child, marrying).

\section{Conclusions}

While the impact of a workplace relocation may lead to a shift from public transport mode to a private one, concluding that the new worksite leads to a less sustainable mobility behavior appears short-sighted. Indeed, due to mode choice inertia [1], the "movers" might continue or start to use car to keep that travel time acceptable but the "newcomers" might have a different modal split. While workers who relocate might be better off because of faster commuting and the use of a "superior form of transportation" (the car) the social and environmental impact might be negative [23]. Even in case of invariant commuting distance after an office relocation, the energy needed by the employees to reach their new worksite is perceived as significantly bigger [11].

While workplace decentralization was reported to lead to shorter commuting time partly because of a less congested road network [17], an increasing number of firms moving to specific sub-centers may badly affect the local network. On the other side, decentralization by moving company location 
from the center to the periphery might decrease crowding in public transport lines directed towards the city-center, to the advantage of workers commuting therein.

Many, but not all considered scientific studies have underlined an increase in the share of car commuters after workplace decentralization. However, as pointed out by [2], there is no causal relation, workplace relocations do not lead ipso facto to higher car use among workers. Sim et al. [21] conclude that in Singapore, a place exhibiting high reliability public transport services, workplace relocations have the potential to lead to lower car use for commuting trips. Walker et al. [45] showed also that car use increase after a workplace relocation is not automatically leading to higher share of private vehicle use for the home-to-work trip.

\section{Implications for Transport Policy and the Need for Mobility Management}

While a relocation can have a detrimental effect on the commuting mobility, it does not mean that the new location is unsustainable regarding transportation. A workplace relocation from the city CBD to a peripheral Transit Oriented Development (TOD) area will likely generate an unsustainable modal shift from the movers, while the aggregated modal share of the newcomers might be virtuous. Such trend has never been reported in the scientific literature, but it is expected that, in the long run, the aggregated modal split will converge to the modal split of the new-coming employees. Building density also seems to matter, because a 10-storey decentralized office will exhibit a $4 \%$ higher transit use compared to a 1-storey building. Thus, clearly, when developing decentralized office centers, planners should keep in mind that a bigger suburban project with high and mixed-use buildings will positively affect public transport use. When developing suburban office centers, size counts [47].

Aggregated modal split differentials are mainly due to variation of the relative public transport and road network accessibility, the change in parking management schemes and the share of workers living within short distances [19]. In other words, when assessing the impact of workplace relocation on the commuting behavior, the contexts of both the old and the new workplace are crucial [11].

Without any national or regional policy regarding suburban parking regulations or voluntary sustainable transport strategy, car use will remain an over-attractive commuting alternative [56]. Free parking lots, uncongested (or barely congested) suburban networks will still push workers to use private motorized modes of transportation despite efficient public transport services. Cervero [47] provided an interesting example with two major companies located close-by. The first company provides a non-free parking lot to $34 \%$ of its workers and the second one has 730 free spaces for 650 workers. While at the first company, $35 \%$ of the workers carpool and $12 \%$ come by transit, only $8 \%$ of the employees of the second company carpool and $85 \%$ drive alone.

Mode choice inertia will lead workers to stay with the mode they were using prior to the workplace relocation as long as there is no major commuting time increase [1]. Thus, in order to anticipate commuting mode shift due to an office suburbanization, the modal split before the relocation is an acceptable benchmark value. However, as pointed out by Walker et al. [45], the workplace relocation can be considered as a discontinuity in the habitual commuting pattern and thus can potentially be a good opportunity to push away workers from Single Occupant Vehicles with tailored transport and mobility management policies. Thus, depending on the involvement level of the different parties (regional authorities, city government, private and public institutions), whether a specific planning policy or a "laissez-faire" approach is implemented in terms of travel behavior-more specifically car use-workplace relocations could be seen at the same time as a potential threat or an unexpected opportunity. In this respect workplace travel plans can be regarded as important tools to engage employers in promoting sustainable travel choices. Travel Plans have been implemented to secure the permission for relocations in UK [57]. An analysis of 19 case studies showed that travel plans resulted in $52 \%$ of the car users were persuaded to use alternative modes to the car. Another notable example of successful travel planning is reported in the TravelSmart Workplace program adopted in Perth, Australia. By May 2007 the program had supported 22 employers to develop travel plans. Actions implemented under the plans included providing information on travel alternatives, improving 
workplace facilities and offering incentives to change. Travel alternatives were promoted before the move, employees involved in developing the travel plan successfully advocated for good cycle facilities at the new site, and the employer reduced the number of employees given vehicle and parking privileges. Before and after surveys showed that most workplaces reduced car commuting, averaging $-10 \%$ in relative terms [58]. Local experience suggests that expanding and sustaining travel demand management in workplaces depends on integrating travel plan measures into good business practice and building a supportive culture.

Author Contributions: Conceptualization and methodology, F.S. and F.V., literature collection, F.S., A.S.B., and F.V.; writing - review and editing, F.V., F.S., and A.S.B.; visualization, F.S. All authors have read and agreed to the published version of the manuscript.

Funding: This research was supported by the Fonds Nationale de Recherche (project STABLE AFR N. 7951609).

Conflicts of Interest: The authors declare no conflict of interest.

\section{References}

1. Vale, D.S. Does commuting time tolerance impede sustainable urban mobility? Analysing the impacts on commuting behaviour as a result of workplace relocation to a mixed-use centre in Lisbon. J. Transp. Geogr. 2013, 32, 38-48. [CrossRef]

2. Yang, X.; Day, J.E.; Langford, B.C.; Cherry, C.R.; Jones, L.R.; Han, S.S.; Sun, J. Commute responses to employment decentralization: Anticipated versus actual mode choice behaviors of new town employees in Kunming, China. Transp. Res. Part D Transp. Environ. 2017, 52, 454-470. [CrossRef]

3. Bamberg, S. Is a residential relocation a good opportunity to change people's travel behavior? Results from a theory-driven intervention study. Environ. Behav. 2006, 38, 820-840. [CrossRef]

4. Rau, H.; Manton, R. Life events and mobility milestones: Advances in mobility biography theory and research. J. Transp. Geogr. 2016, 52, 51-60. [CrossRef]

5. Schoenduwe, R.; Mueller, M.G.; Peters, A.; Lanzendorf, M. Analysing mobility biographies with the life course calendar: A retrospective survey methodology for longitudinal data collection. J. Transp. Geogr. 2015, 42, 98-109. [CrossRef]

6. Bell, D.A. Office location-City or suburbs? Travel impacts arising from office relocation from city to suburbs. Transportation 1991, 18, 239-259.

7. Sprumont, F.; Astegiano, P.; Viti, F. On the consistency between commuting satisfaction and traveling utility: The case of the University of Luxembourg. Eur. J. Transp. Infrastruct. Res. 2017, 17, 248-262.

8. Zarabi, Z.; Lord, S. Toward More Sustainable Behavior: A Systematic Review of the Impacts of Involuntary Workplace Relocation on Travel Mode Choice. J. Plan. Lit. 2019, 34, 38-58. [CrossRef]

9. van Ommeren, J. Commuting and Relocation of Jobs and Residences; Routledge: Abingdon, UK, 2000.

10. De Witte, A.; Hollevoet, J.; Dobruszkes, F.; Hubert, M.; Macharis, C. Linking modal choice to motility: A comprehensive review. Transp. Res. Part A Policy Pract. 2013, 49, 329-341. [CrossRef]

11. Naess, P.; Sandberg, S.L. Workplace location, modal split and energy use for commuting trips. Urban Stud. 1996, 33, 557-580. [CrossRef]

12. Van Wee, B.; Banister, D. How to Write a Literature Review Paper? Transp. Rev. 2016, 36, 278-288.

13. Wabe, J.S. Office Decentralisation: An Empirical Study. Urban Stud. 1966, 3, 35-55. [CrossRef]

14. Daniels, P.W. Office decentralization from London—Policy \& practice. Reg. Stud. 1969, 3, 171-178.

15. Daniels, P.W. Employment Decentralization and the Journey to Work. Area 1970, 2, 47-51.

16. Daniels, P.W. Transport changes generated by decentralized offices. Reg. Stud. 1972, 6, 273-289. [CrossRef]

17. Hanssen, J.U. Transportation impacts of office relocation: A case study from Oslo. J. Transp. Geogr. 1995, 3, 247-256. [CrossRef]

18. Cervero, R.; Wu, K.-L. Sub-centring and commuting: Evidence from the San Francisco Bay Area, 1980-1990. Urban Stud. 1998, 35, 1059-1076. [CrossRef]

19. Aarhus, K. Office location decisions, modal split and the environment: The ineffectiveness of Norwegian land use policy. J. Transp. Geogr. 2000, 8, 287-294. [CrossRef]

20. Malone-Lee, L.C.; Sim, L.L.; Chin, L. Planning for a more balanced home-work relationship: The case study of Singapore. Cities 2001, 18, 51-55. [CrossRef] 
21. Sim, L.L.; Malone-Lee, L.C.; Chin, K.H.L. Integrating land use and transport planning to reduce work-related travel: A case study of Tampines Regional Centre in Singapore. Habitat Int. 2001, 25, 399-414. [CrossRef]

22. Aguiléra, A.; Wenglenski, S.; Proulhac, L. Employment suburbanisation, reverse commuting and travel behaviour by residents of the central city in the Paris metropolitan area. Transp. Res. Part A Policy Pract. 2009, 43, 685-691. [CrossRef]

23. Cervero, R.; Landis, J. Suburbanization of jobs and the journey to work: A submarket analysis of commuting in the San Francisco bay area. J. Adv. Transp. 1992, 26, 275-297. [CrossRef]

24. Gordon, P.; Kumar, A.; Richardson, H.W. Congestion, changing metropolitan structure, and city size in the United States. Int. Reg. Sci. Rev. 1989, 12, 45-56. [CrossRef]

25. Gordon, P.; Richardson, H.W.; Jun, M.-J. The commuting paradox evidence from the top twenty. J. Am. Plan. Assoc. 1991, 57, 416-420. [CrossRef]

26. Giuliano, G.; Small, K.A. Subcenters in the Los Angeles region. Reg. Sci. Urban Econ. 1991, 21, $163-182$. [CrossRef]

27. Dubin, R. Commuting Patterns and Firm Decentralization. Land Econ. 1991, 67, 15-29. [CrossRef]

28. Von Behren, S.; Puhe, M.; Chlond, B. Office relocation and changes in travel behavior: Capturing the effects including the adaptation phase. Transp. Res. Procedia 2018, 32, 573-584. [CrossRef]

29. Patella, S.M.; Sportiello, S.; Petrelli, M.; Carrese, S. Workplace relocation from suburb to city center: A case study of Rome, Italy. Case Stud. Transp. Policy 2019, 7, 357-362. [CrossRef]

30. Rau, H.; Popp, M.; Namberger, P.; Mögele, M. Short distance, big impact: The effects of intra-city workplace relocation on staff mobility practices. J. Transp. Geogr. 2019, 79, 102483. [CrossRef]

31. Sprumont, F.; Viti, F.; Caruso, G.; König, A. workplace relocation and mobility changes in a transnational metropolitan area: The case of the University of Luxembourg. Transp. Res. Procedia 2014, 4, 286-299. [CrossRef]

32. Burke, M.I.; Li, T.; Dodson, J. What happens when government workers move to the suburbs? Impact on transport of planned decentralization of employment in Brisbane, Australia. Transp. Res. Rec. 2011, 2255, 110-116. [CrossRef]

33. Li, T.; Burke, M.; Dodson, J. Transport impacts of government employment decentralization in Australian city-Testing scenarios using transport simulation. Socio-Econ. Plan. Sci. 2017, 58, 63-71. [CrossRef]

34. Frater, J.; Vallance, S.; Young, J.; Moreham, R. Disaster and unplanned disruption: Personal travel planning and workplace relocation in Christchurch, New Zealand. Case Stud. Transp. Policy 2019, 8, 500-507. [CrossRef]

35. Alpkokin, P.; Cheung, C.; Black, J.; Hayashi, Y. Dynamics of clustered employment growth and its impacts on commuting patterns in rapidly developing cities. Transp. Res. Part A 2008, 42, 427-444. [CrossRef]

36. STATEC. Available online: https://statistiques.public.lu/fr/acteurs/statec/index.html (accessed on 10 September 2020).

37. MMTP. Available online: https://ransports.public.lu/fr/publications/situation-actuelle/enquete-luxmobil2017/enquete-Luxmobil.html (accessed on 10 September 2020).

38. MMTP. Available online: https://transports.public.lu/fr/contexte/strategie/modu2.html/ (accessed on 10 September 2020).

39. Decoville, A.; Klein, O. The limits of polycentrism at the city-regional scale: The case of Luxembourg. Eur. J. Spat. Dev. 2014, 1, 1-20.

40. Chilla, T.; Schulz, C. Spatial development in Luxembourg: Mimetic evolution or emergence of a new planning culture? Eur. Plan. Stud. 2015, 23, 509-528. [CrossRef]

41. Sprumont, F.; Viti, F. The effect of workplace relocation on individuals' activity travel behavior. J. Transp. Land Use 2018, 11, 985-1002. [CrossRef]

42. Daniels, P.W. Transport changes generated by decentralized offices: A second survey. Reg. Stud. 1981, 15, 507-520. [CrossRef]

43. Wabe, J.S. Dispersal of employment and the journey to work: A case study. J. Transp. Econ. Policy 1967, 1, 345-361.

44. Levinson, D.M.; Kumar, A. The rational locator: Why travel times have remained stable. J. Am. Plan. Assoc. 1994, 60, 319-332. [CrossRef]

45. Walker, I.; Thomas, G.O.; Verplanken, B. Old habits die hard: Travel habit formation and decay during an office relocation. Environ. Behav. 2015, 47, 1089-1106. [CrossRef] 
46. Gerber, P.; El-Geneidy, A.; Manaugh, K.; Lord, S. From workplace attachment to commuter satisfaction before and after a workplace relocation. Transp. Res. Part F Traffic Psychol. Behav. 2020, 71, 168-181. [CrossRef]

47. Cervero, R. Land Uses and Travel at Suburban Activity Centers; Working Paper; University of California Transport Center: Berkeley, CA, USA, 1991.

48. Angel, S.; Blei, A.M. The productivity of American cities: How densification, relocation, and greater mobility sustain the productive advantage of larger U.S. metropolitan labor markets. Curr. Res. Cities 2016, 51, 36-51. [CrossRef]

49. Kim, C. Commuting time stability: A test of a co-location hypothesis. Transp. Res. Part A Policy Pract. 2008, 42, 524-544. [CrossRef]

50. Zarabi, Z.; Gerber, P.; Lord, S. Travel satisfaction vs. life satisfaction: A weighted decision-making approach. Sustainability 2019, 11, 5309. [CrossRef]

51. Vega, A.; Reynolds-Feighan, A. A methodological framework for the study of residential location and travel-to-work mode choice under central and suburban employment destination patterns. Transp. Res. Part A Policy Pract. 2009, 43, 401-419. [CrossRef]

52. van Ommeren, J.; Rietveld, P.; Nijkamp, P. Residence and workplace relocation: A bivariate duration model approach. Geogr. Anal. 1996, 28, 315-329. [CrossRef]

53. Olaru, D.; Smith, N.; Marquez, L.; McNamara, C. Presenting impacts of office relocation on staff travel. In Proceedings of the 26th Conference of Australian Institutes of Transport Research (CAITR), Melbourne, Australia, 8-10 December 2004.

54. Perchoux, C.; Kestens, Y.; Thomas, F.; Hulst, A.V.; Thierry, B.; Chaix, B. Assessing patterns of spatial behavior in health studies: Their socio-demographic determinants and associations with transportation modes (the RECORD Cohort Study). Soc. Sci. Med. 2014, 119, 64-73. [CrossRef] [PubMed]

55. De Vos, J.; Derudder, B.; Van Acker, V.; Witlox, F. Reducing car use: Changing attitudes or relocating? The influence of residential dissonance on travel behavior. J. Transp. Geogr. 2012, 22, 1-9. [CrossRef]

56. Cumming, I.; Weal, Z.; Afzali, R.; Rezaei, S.; Idris, A.O. The impacts of office relocation on commuting mode shift behaviour in the context of Transportation Demand Management (TDM). Case Stud. Transp. Policy 2019, 7, 346-356. [CrossRef]

57. Cairns, S.; Newson, C.; Davis, A. Understanding successful workplace travel initiatives in the UK. Transp. Res. Part A Policy Pract. 2010, 44, 473-494. [CrossRef]

58. Wake, D. Reducing car commuting through employer-based travel planning in Perth, Australia. TDM Rev. 2007, 15, 11-13.

(C) 2020 by the authors. Licensee MDPI, Basel, Switzerland. This article is an open access article distributed under the terms and conditions of the Creative Commons Attribution (CC BY) license (http://creativecommons.org/licenses/by/4.0/). 